\title{
Fémelem-homeosztázis és oxidatív stressz patológiás folyamatokban
}

\author{
Szentmihályi Klára dr. \\ MTA Természettudományi Kutatóközpont, Anyag- és Környezetkémiai Intézet, Budapest
}

\begin{abstract}
A szerző röviden összefoglalja az oxidatív stressz és a fémion-metabolizmus megváltozása közötti összefüggéseket patológiás folyamatokkal kapcsolatban. Az esszenciális fémionok, mint például a $\mathrm{Ca}, \mathrm{Mg}, \mathrm{Fe}, \mathrm{Cu}, \mathrm{Zn}, \mathrm{Se}$, nélkülözhetetlenek az élő szervezetben, metabolizmusuk és sejten belüli koncentrációjuk szigorúan szabályozott. A külső vagy belső tényező hatására megváltozott fémion-metabolizmus fémion-akkumulációt vagy fémionhiányt idézhet elő. A felesleges mennyiségben jelen lévő redoxaktív esszenciális fémek, mint például a $\mathrm{Fe}, \mathrm{Cu}, \mathrm{Co}, \mathrm{Cr}, \mathrm{Ni}$, bizonyos körülmények között szabad gyököket képesek indukálni, amelyek gyulladást, sejtkárosodást és daganatos elváltozásokat okoznak, bár a molekuláris mechanizmus még mindig nem tisztázott minden részletében. A nem esszenciális és nem változó vegyértékú fémionok metabolizmusának megváltozása is hatással van a redoxhomeosztázisra. Annak ellenére, hogy minden egyes fém egyedi módon és különböző mechanizmussal reagálhat, hasonló folyamatok játszódnak le, melyek során mind a fémhiány, mind a túlzott mennyiségű fém oxidatív stresszt vált ki. Károsodik az antioxidáns védekezőrendszer, a termelődő szabad gyökök megváltoztatják a redoxegyensúlyt, és a redoxhomeosztázis megváltozása kiváltja a citokinek és más transzkripciós faktorok termelését, amelyek befolyásolják az intracelluláris jelátviteli utakat, és hatással vannak különböző betegségek, így az anyagcsere-, szív- és érrendszeri betegségek, neurológiai betegségek és a tumor kialakulására is.
\end{abstract}

Orv Hetil. 2019; 160(36): 1407-1416.

Kulcsszavak: fémek, oxidatív stressz, patológiás folyamatok

\section{Metal element homeostasis and oxidative stress in pathological processes}

The author briefly summarizes the relationship between oxidative stress and changes in metal ion metabolism in pathological processes. Essential metal ions such as $\mathrm{Ca}, \mathrm{Mg}, \mathrm{Fe}, \mathrm{Cu}, \mathrm{Zn}$, Se are essential in the living organisms, their metabolism and intracellular concentration are strictly regulated. Externally or intrinsically, altered metal ion metabolism can lead to metal ion accumulation or metal ion deficiency. Excess amounts of redox-active essential metals such as $\mathrm{Fe}, \mathrm{Cu}, \mathrm{Co}, \mathrm{Cr}, \mathrm{Ni}$ can induce free radicals under certain circumstances that cause inflammation, cell damage, and cancerous changes, although the molecular mechanism is still unclear in every detail. Changes in the metabolism of non-essential and non-variable valence metal ions also affect redox homeostasis. Despite the fact that each metal can react in a unique way and with different mechanisms, similar processes occur, where both metal deficiency and excessive metal induce oxidative stress. Antioxidant defense system is damaged, free radicals produced alter the redox balance, and redox homeostasis changed induces the production of cytokines and other transcription factors that affect the intracellular signaling pathways and affect the development of various diseases, including metabolic, cardiovascular, neurological diseases and cancer.

Keywords: metals, oxidative stress, pathological processes

Szentmihályi K. [Metal element homeostasis and oxidative stress in pathological processes]. Orv Hetil. 2019; 160(36): 1407-1416.

(Beérkezett: 2019. április 5.; elfogadva: 2019. április 25.)

\section{Rövidítések}

$\mathrm{A} \beta=$ amiloid $-\beta$ peptid $; \mathrm{AK}=$ Alzheimer-kór; $\mathrm{Akt}=$ szignáltransz dukciós út; $\mathrm{APl}=$ aktivátor protein- $1 ; \mathrm{ATP}=$ adenozin -5 '-trifoszfát; $c$ AMP $=($ cyclic adenosine monophosphate $)$ ciklikus adenozin-monofoszfát; Cdk5 = (cyclin-dependent kinase 5 ) ciklinfüggő kináz-5; cSrc = tirozin-kináz; DAG = diacil-glicerol; DMTl $=($ divalent metal transporter 1$)$ kétértékú fémtranszporter-1; DNS = dezoxiribonukleinsav; eNOS $=($ endo- 
thelial nitric oxide synthase) endothelialis nitrogén-oxid-szintáz; EGF $=$ (epidermal growth factor $)$ epidermális növekedési faktor; $\mathrm{EGFR}=$ (estimated glomerular filtration rate) becsült glomerulusfiltrációs ráta; $\mathrm{ERKl} / 2=$ (extracellular signal-regulated kinase-1 and -2) extracelluláris szignálszabályozott kináz-1/2; FceRl = immunglobulin-epszilon-receptor; GPx = glutation-peroxidáz; GSH = glutation; GSK3 = $($ glycogen synthase kinase 3) glikogén-szintáz-kináz-3; GSSG = oxidált glutation, glutation-diszulfid; HIFl $\alpha=$ (hypoxia-inducible factor 1 alpha subunit) hypoxiaindukált faktor- 1 -alfa; His = hisztidin; $\mathrm{I} \kappa \mathrm{B} \alpha=$ (regulatory protein that inhibits $\mathrm{NF} \kappa \mathrm{B}$ ) $\mathrm{NF} \kappa \mathrm{B}$ gátlását szabályozó protein; $\operatorname{IKK} \beta=$ (inhibitor of nuclear factor kappa-B kinase subunit beta) $\mathrm{NF} \kappa \mathrm{B}$-inhibitor; IL1 $\beta,-6=$ interleukinok; iNOS $=$ (inducible nitric oxide synthase) indukálható nitrogén-oxid-szintáz; $\mathrm{IP}_{3}=$ inozitol-1,4,5-trifoszfát; JNK = (c-Jun $\mathrm{N}$-terminal kinase) c-Jun $\mathrm{N}$-terminális kináz; LDL $=$ (low density lipoprotein) alacsony sưrűségú lipoprotein; MAPK = mitogénaktivált proteinkináz; $\mathrm{MDA}=$ malondialdehid; $\mathrm{Mdrl}$ $=($ multi-drug resistance gene $)$ multidrogrezisztencia-gén; Met = metionin; $\mathrm{MMP}=$ mátrixmetalloproteináz; $\mathrm{MT}=$ metalloti onein; $\mathrm{MTF} 1=($ metal regulatory transcription factor 1$)$ fémérzékeny transzkripciós faktor-1; NADPH = (nicotinamide adenine dinucleotide phosphate) a nikotinamid-adenin-dinukleotid-foszfát redukált formája; $\mathrm{NF} \kappa \mathrm{B}=$ nukleárisfaktor-kappa$\mathrm{B} ; \mathrm{NO}=$ nitrogén-monoxid; $\mathrm{p} 38-\mathrm{MAPK}=$ p38 mitogénaktivált proteinkináz; p53 = tumorszuppresszor gén; PDGF = (platelet-derived growth factor) thrombocytaeredetű növekedési faktor; $\mathrm{PIP}_{2}=$ foszfatidil-inozitol-diszfoszfát; $\mathrm{PK}=$ Parkinson-kór; $\mathrm{PKC}=$ proteinkináz $\mathrm{C} ; \mathrm{PLC}=$ foszfolipáz $\mathrm{C} ; \mathrm{PrP}^{\mathrm{C}}=$ prionfehérje; $\operatorname{PrP}^{\mathrm{CS}}=$ módosult prionfehérje; RAS = G-proteincsaládba tartozó fehérje; RAS/RAF/MAPK/ERK = RAS/ $\mathrm{RAF} /$ mitogénaktivált proteinkináz/extracelluláris jelszabályozott kináz kaszkád; REFl = redoxfaktor-1; RNS = (reactive nitrogen species) reaktívnitrogén-fajták; $\mathrm{ROS}=($ reactive oxygen species) reaktívoxigén-fajták; RTK $=$ receptor tirozin-kináz; S = kén; SOD = szuperoxid-dizmutáz; Src = SRC-családba tartozó kináz; STAT = (signal transducer and activator of transcription) jelátvitelt közvetítő fehérje; $\mathrm{T}=$ tionein; $\mathrm{TNF} \alpha=$ tumornekrózisfaktor-alfa; Tyr $=$ tirozin; $\mathrm{VEGF}=($ vascular en- dothelial growth factor) vascularis endothelialis növekedési faktor; Zip = cink- és vasregulált transzporter protein; $\mathrm{ZnT}=$ cinktranszporter; ZnT5 = cinktranszporter-5

Az élő szervezetben in vivo képződő szabad gyököket a sejtek endogén antioxidáns védekező enzimrendszere, a szuperoxid-dizmutáz (SOD), a kataláz és a glutationperoxidáz (GPx) kompenzálni képes (1. ábra). A patológiás folyamatok során feleslegben termelődő szabad gyökök megváltoztatják a redoxegyensúlyt, és a redoxhomeosztázis megváltozása kiváltja a citokinek és más transzkripciós faktorok termelését, amelyek befolyásolják az intracelluláris jelátviteli utakat, és hatással vannak különböző betegségek, így például a tumor kialakulására [1].

A redoxjelátviteli út és az angiogenezis aktiválódásának oka lehet patológiás folyamatban a reaktívoxigén-fajták (ROS) endogén képződése, fooleg a $\mathrm{NAD}(\mathrm{P}) \mathrm{H}$-oxidázok által termelt szuperoxidanion-gyökök $\left(\mathrm{O}_{2}^{-}\right)$, a reaktívnitrogén-fajták (RNS), valamint a tiolgyökök termelődése [2]. Mindemellett más faktorok, folyamatok is képesek szabad gyököket generálni, például a stressz, a fény, a hő. Számos transzkripciós faktor, redoxérzékeny gének aktiválódnak (például HIFl $\alpha, \mathrm{REFl}, \mathrm{p} 53, \mathrm{NF} \kappa \mathrm{B}$, VEGF, MMP-k) az angiogenezisben különböző jelátviteli utakon (például cSrc, Akt, eNOS, p38-MAPK, $\mathrm{ERKl} / 2$ ) (2. ábra) [3].

Az oxidatív stressz fémelemhiányt okoz a sejtekben és a szövetekben, és ez a fémfüggő antioxidáns védelmi rendszer alulmúködéséhez vezet, ahogy csökkent CuZnSOD-aktivitás figyelhető meg, bár ezzel párhuzamosan megnövekedett MnSOD-aktivitást mutattak ki [4]. A reaktívoxigén- vagy -nitrogén-gyökök indukálta oxidatív, illetve nitrozatív stressz a metallotionein oxidációját okozhatja, és a cink-tioneinból szabad cinkion

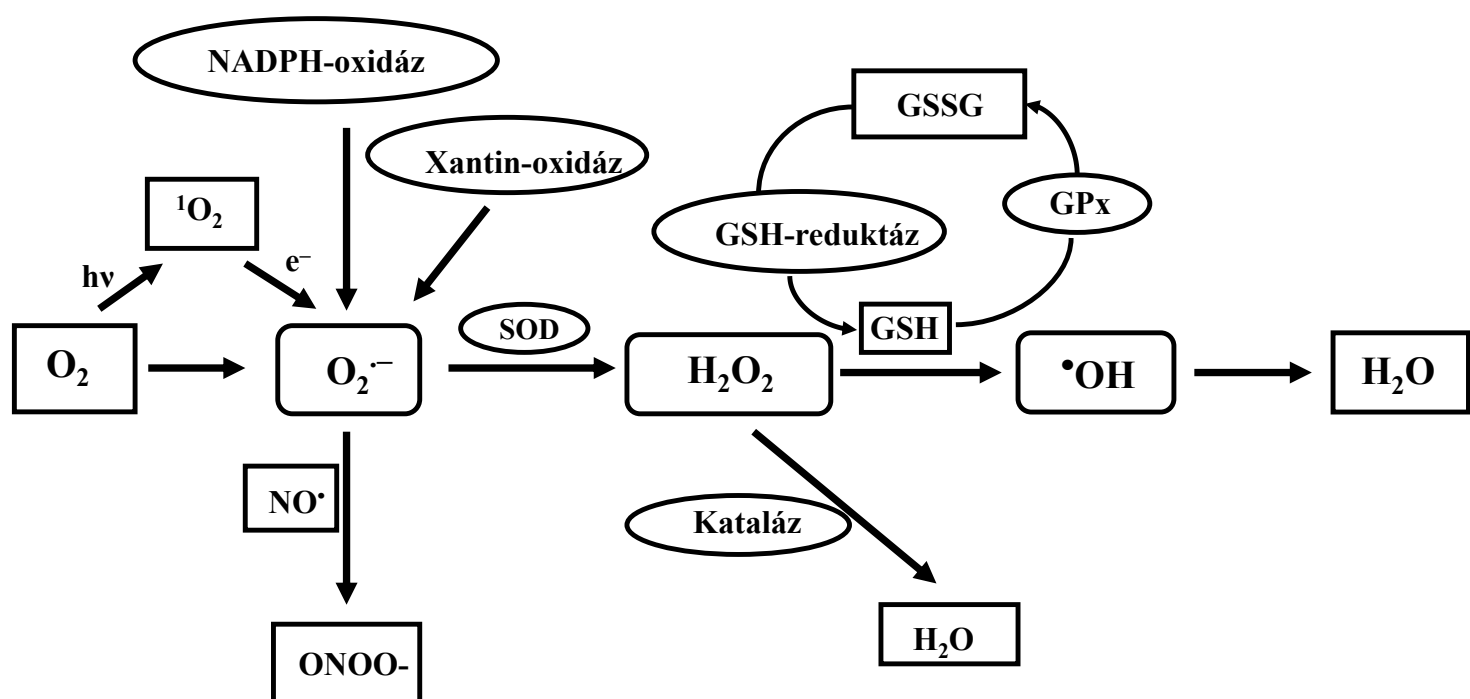

1. ábra | Szabad gyökök semlegesítése az endogén antioxidáns védekezőrendszerrel 


\section{Oxidatív stressz}

(hő, sugárzás, vegyszer, szennyezők, fény stb.)

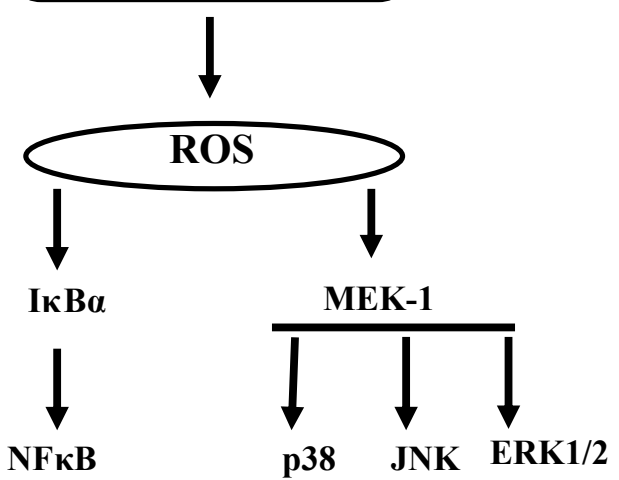

2. ábra nem tisztázott, hogy mi az elsődleges folyamat: az oxidatív stressz váltja ki a fémionhiányt, vagy a fémionhiány okozta antioxidáns védekezőrendszer károsodása váltja ki az oxidatív stresszt.

\section{Fémionterhelés}

A felesleges mennyiségben jelen lévő redoxaktív esszenciális fémek, mint például a $\mathrm{Fe}, \mathrm{Cu}, \mathrm{Co}, \mathrm{Cr}, \mathrm{Ni}$, bizonyos körülmények között szabad gyökök képződését indukálják biológiai rendszerekben, amelyek gyulladást, sejtkárosodást és tumort okoznak, bár a molekuláris mechanizmus még mindig nem tisztázott minden részletében. Ennek a folyamatnak és az említett fémek e tulajdonságának legfóbb magyarázata az, hogy ezek a fémek betöltetlen d-elektronpályával rendelkeznek, és egy vagy több párosítatlan elektront tartalmaznak, attól függöen, hogy milyen a redoxiállapotuk. Annak ellenére, hogy minden egyes fém egyedi módon és különböző mechanizmussal reagálhat, hasonló folyamatok játszódnak le, melyek során a túlzott mennyiségü fém oxidatív stresszt vált ki. A folyamat közös jellemzője, hogy a fémelemek aktiválják a NFkB transzkripciós faktort, valamint a következő faktorokat is befolyásolják: növekedési faktorok, Src kináz, RAS-jelátvitel, MAPK, foszfoinozitid-3-foszfát/Akt útvonal, AP1, p53 és HIFl $\alpha$ [8].

A fémek a növekedési faktorok közül az EGF, a PDGF és a VEGF aktiválására is képesek, melyek jelentős szerepet játszanak a fémionok által okozott karcinogenezisben. A növekedési faktorok funkcionális vagy más jellegú módosulása elsősorban húgyúti vagy tüdőtumoros megbetegedéseket is okozhat [9]. A PDGF túlzott expressziójához vezethet a $\mathrm{Ni}$ - vagy Co-aktiváció, ami tumoros megbetegedést válthat ki a tüdőben vagy a prosztatában [10]. Az EGF részt vesz a proliferációban és az angiogenezisben. A Ni képes növelni az EGF-receptor expresszióját, az As az EGF-receptorok foszforilezését, a MAPK kinázok (MAPKKl és 2) és az ERKl/2 aktiválását [11]. A VEGF szerepet játszik a proliferációban és az angiogenezisben is. Hypoxia esetén Ni vagy Co hatására VEGF aktiválódik, azonban a VEGF expressziója As hatására következhet be. Az EGF, a VEGF vagy a PDGF aktiválásával az intracelluláris kalciumkoncentráció megnövekszik [12].

Egyfajta fém nagy mennyiségű bevitele megváltoztathatja más fémek homeosztázisát. Például arany nagy mennyiségú bevitele injekció formájában a vese-Cu- és -Zn-szintek emelkedését okozza, de a Zn-kezelés negatív hatással van a $\mathrm{Cu}$-szintre patkányvesében és -májban. Ezüstöt tartalmazó injekció növeli az $\mathrm{Ag}, \mathrm{Cu}$ és $\mathrm{Zn}$ szintjét patkányvesében és -májban [13]. Azonban más faktorok is befolyásolhatják a fémfelhalmozódást, a metallotionein nagyobb expressziója növeli például a $\mathrm{Cu}$, a Zn és a Cd akkumulációját patkányvesében és -májban, bár a felhalmozódás különböző mértékű volt [14]. 


\section{Fémelem-homeosztázis és táplálkozás}

Nem megfelelő esszenciális fémelembevitel vagy valamilyen betegség következtében a szervezetben makro- és mikroelemekben hiány alakulhat ki (például anaemia), ami kisebb elemszintet eredményez a plazmában és a májban. Ez az állapot növeli az élelmiszerekkel felvett nem esszenciális és/vagy toxikusnak nevezett elemek abszorpcióját, majd ezen elemek koncentrációját a sejtekben és a szervekben, aminek következtében helyettesíthetik az esszenciális elemeket a fehérjékben, enzimekben is [15]. A sejtben nem megfelelő fémion-ellátottság csökkenti egyes fehérjék és enzimek szintézisét, illetve szintézislépéseit, így az antioxidáns védelmi rendszer sérül. Általános magnéziumhiány vagy a kalciumcsatornákon keresztül beáramló nagyobb mennyiségű Ca például PLC-katalízissel $\mathrm{IP}_{3}$-képződés aktivációját okozza, ami további intracelluláris kalciumkoncentráció növekedését vonja maga után $\mathrm{Ca}^{2+}$-ionok felszabadításával az endoplazmatikus reticulum raktáraiból. A $\mathrm{Ca}^{2+}$-ionok aktiválják a PKC-t, majd a Raf-kináz a MAPK-t, ami aktiválja a citokinek felszabadulását, és a jól ismert szignálúton oxidatív stresszt indukál (4. ábra) [16].

A fémionok nagyobb mértékű bevitele táplálkozással vagy táplálékkiegészítőkkel nagyobb abszorpciót és ebből adódóan nagyobb fémion-koncentrációt eredményezhet. Normális táplálkozással ritkán fordul elő túlzott fémionbevitel több ok miatt: a táplálékokban komplexen kötött fémionok döntően aktív transzporttal jutnak a szervezetbe, ami nem koncentrációfüggő, valamint a visszacsatolási rendszer miatt. A táplálékkiegészítők esetén az alkalmazott fémkomplex, illetve fémsó kémiai szerkezete is befolyásolja a felszívódás formáját és mértékét [17]. Megnőhet a passzív transzporttal, illetve facilitált diffúzióval történő felszívódás, melynek következtében a sejtekbe bejutott felesleges átmeneti fémionok képesek szabad gyököket gerjeszteni a Fenton- vagy
Fenton-típusú reakcióval [7]. A kalcium nagyobb menynyiségben történő bejutása esetén az extracelluláris tér Ca-szintjének emelkedése aktiválja a kalciumérzékeny receptorokat, ami a plazmamembrán citoszol felőli oldalán aktivál egy G-proteint, majd ez aktiválja a PLC-t, és katalizálja a $\mathrm{PIP}_{2}$ hidrolízisét $\mathrm{IP}_{3}$-tá és DAG-lá (4. ábra). A folyamat az ismert úton oxidatív stresszhez vezet [16].

$\mathrm{Az}$ alkoholos italok fogyasztása növelheti a máj- és prosztatatumor kockázatát nagyivók esetén, de napi több mint $10 \mathrm{~g}$ alkohol fogyasztása is növeli a száj- és toroktumor kockázatát [18]. Az alkoholizmusban cinkés mangánhiány alakul ki. Női önkéntesek esetében a magnézium- és a cinkszint jelentős csökkenését figyelték meg egy hónapos vörösborfogyasztást $(250 \mathrm{ml} /$ hét) követően, és csökkenő tendenciát tapasztaltak a rézszintekben mindkét nem esetében, valamint a magnézium- és a cinkszintben férfiaknál [19]. Króm-, magnézium-, mangán- és cinkhiány alakulhat ki cukorbetegségben, és a cink hiánya sok bőrbetegség esetében is előfordul [20].

\section{A szabadgyök-képződés fém katalizálta folyamatai és a jelátvitel}

Az átmeneti fémionok képesek szabad gyököket gerjeszteni Fenton- vagy Fenton-típusú reakcióval [7]. A vas katalizálta gyökképződést Fenton-reakciónak, míg a többi redoxaktív átmeneti fémion által katalizált gyökképződési folyamatot Fenton-típusú reakciónak hívjuk. A klasszikus Fenton-reakciót több mint 140 évvel ezelőtt, 1876-ban írta le H. J. H. Fenton, amelyben a $\mathrm{Fe}^{2+}$-ion $\mathrm{H}_{2} \mathrm{O}_{2}$-ból hidroxilgyököt indukál borkősav jelenlétében a következő reakció szerint:

$$
\mathrm{Fe}^{2+}+\mathrm{H}_{2} \mathrm{O}_{2} \rightarrow \mathrm{Fe}^{3+}+\cdot \mathrm{OH}+\mathrm{OH}^{-}
$$

$\mathrm{A} \mathrm{Co}^{2+}$ hidrogén-peroxiddal képes a DNS-fehérjék térhálósodását előidézni. A kobalt túladagolása vagy ex-

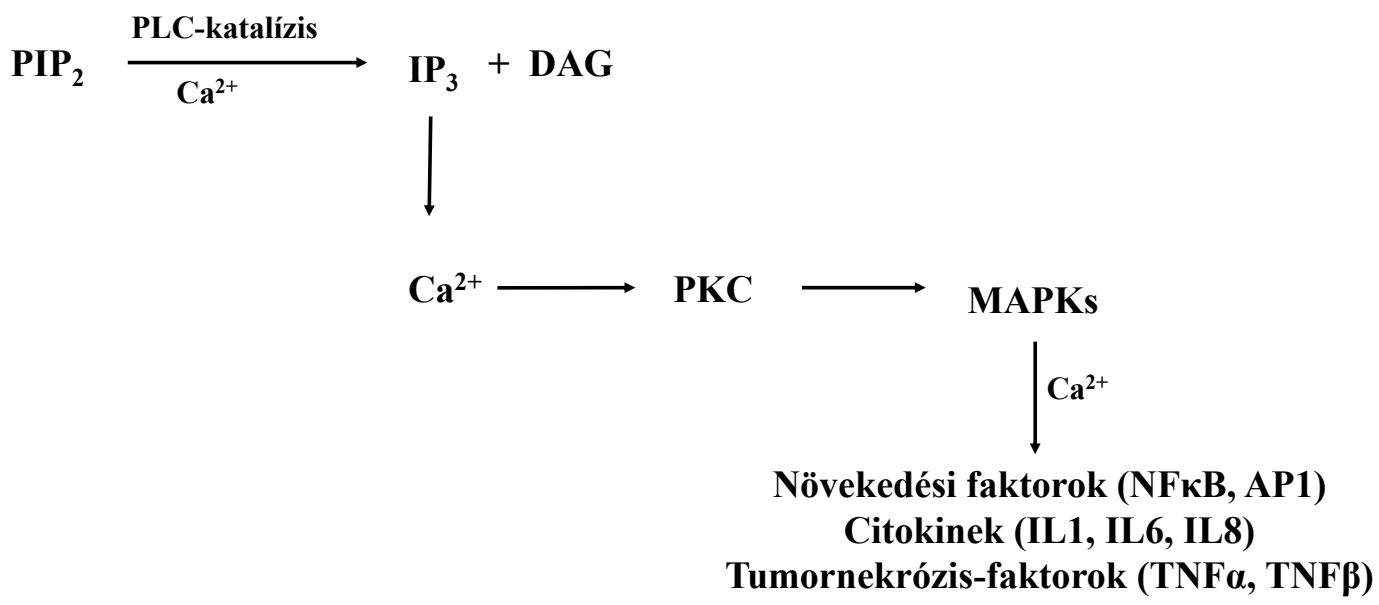

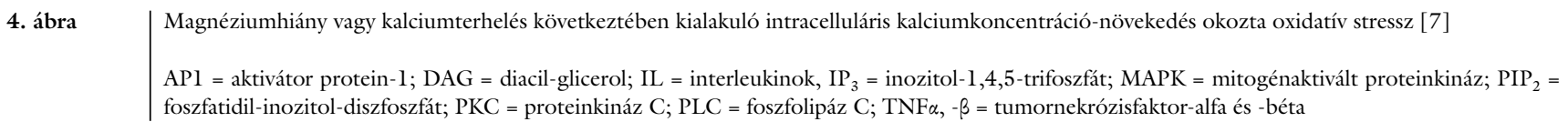


pozíciója hidroxil szabad gyök képződését eredményezheti [21], mely folyamat első lépése a $\mathrm{Co}(\mathrm{I})$ - vagy $\mathrm{Co}(\mathrm{II})$-kelát-komplex Fenton-típusú reakciója az alábbiak szerint:

$$
\begin{aligned}
& \mathrm{Co}^{1+}+\mathrm{H}_{2} \mathrm{O}_{2} \rightarrow \mathrm{Co}^{2+}+\mathrm{OH}^{-}+\cdot{ }^{\cdot} \mathrm{OH} \\
& \left(\mathrm{Co}^{2+}\right) \text {-kelát }+\mathrm{H}_{2} \mathrm{O}_{2} \rightarrow\left(\mathrm{Co}^{3+}\right) \text {-kelát }+\mathrm{OH}^{-}+\cdot{ }^{\cdot} \mathrm{OH}
\end{aligned}
$$

Különleges eset fordul elő a krómnál. Az esszenciális króm(III) csak a normális abszorpciós útvonalon, energiafüggő módon képes abszorbeálódni. Így ha krómfelesleg van a sejtekben, akkor az a vízben oldódó karcinogén króm(VI) által jut a szervezetbe, amely képes átjutni a sejtmembránokon. A nyál, a gyomornedv, az aszkorbinsav és a glutation is képes redukálni a króm(VI)-ot króm(III)-má, méregtelenítve azt, majd folytatódik a vérben, a tüdőben és a májban a króm(III)-má történő átalakulás. Ily módon viszonylag nagyobb mennyiségú króm(III) juthat a sejtekbe, ami oxidatív stresszt okozhat [22]. A flavoenzimek, a glutation-reduktáz vagy a lipoil-dehidrogenáz is képes redukálni a $\mathrm{Cr}(\mathrm{VI})$-ot gyökös közbenső termékek előállításával. Ez az endogén méregtelenítôrendszer korlátozott kapacitással rendelkezik, így a fennmaradó króm(VI) kifejti toxikus hatását [23].

A szervetlen arzén expozíciója okozta karcinogenezis jól ismert és tanulmányozott. Az arzén leginkább toxikus oxidációs állapota az arzén(III), amely tiolcsoportokon keresztül képes különböző fehérjékhez kötődni, és az oxidatív stresszt egy Fenton-szerű reakció adja, amikor az arzén(III) átalakul arzén(IV)-gyé [24].

Egyes fémek közvetlenül nem vesznek részt Fentontípusú reakcióban szabad gyököket generálva, bár közvetve képesek ROS-t és RNS-t termelni, mint a hidrogén-peroxid vagy a nitrogén-oxid. Így például a kadmium különféle fehérjékhez kötődhet, helyettesítve vagy kiszorítva a vasat vagy a rezet, aminek következtében nagyobb mennyiségű szabad fémion képződik oxidatív stresszt előidézve Fenton- és Fenton-típusú reakciók révén [25]. Ugyanakkor az antioxidáns enzimek, mint például a SOD, a kataláz, a glutation-peroxidáz aktivitása kisebb mennyiségú fém hatására növekszik, míg nagyobb menynyiségú fém hatására csökken. E folyamatot a fémion minősége is befolyásolja időfüggő módon, vagyis a gyors aktivitásnövekedést általában aktivitáscsökkenés követi. A kadmiumnak nem teljesen ismert a kiválasztási, kiürülési mechanizmusa, azt azonban tudjuk, hogy a kadmium-metallotionein komplexből a vese tubularis sejtjeiben felszabadul a kadmium, amely részben kiürül. Amennyiben a felszabadult kadmium mennyisége elér egy bizonyos szintet, akkor ott felhalmozódik, a tubularis sejtek károsodását idézve elő, ami a kiürülését gátolja, és a kiürülési ideje körülbelül 40-45 év. Ezért a kadmium esetleges akkumulációja hosszan tartó, évekig elhúzódó oxidatív stresszt okozhat, és növelheti a karcinogenezis kockázatát [26].
A felhalmozódott mérgező vagy redoxinaktív fémek, mint például a berillium, a kadmium, az ólom vagy az antimon, helyettesíthetik az esszenciális elemeket, és stresszt okozhatnak [27]. Néhány ilyen fém képes kéntartalmú endogén vegyületekkel és fehérjékkel reagálni, így például a glutation kiürülését okozni.

A NADPH-ból származó szuperoxidgyökök sejten belüli képződése képes redukálni és felszabadítani a $\mathrm{Fe}^{3+}-\mathrm{t}$ különböző komplexekből a Haber-Weiss-reakciónak megfelelően, így például a ferritin háromértékủ vasa felszabadulhat, és átalakulhat szabad $\mathrm{Fe}^{2+}$-vé [28].

$$
\text { Haber-Weisss-reakció: } \mathrm{Fe}^{3+}+\mathrm{O}_{2}{ }^{\bullet} \rightarrow \mathrm{Fe}^{2+}+\mathrm{O}_{2}
$$

Ez a felszabadult és redukálódott vasion már részt vehet a Fenton-reakcióban, és az (1) reakció szerint szabad gyököket képez, és oxidatív stresszt vált ki.

Természetesen más redoxaktív fémek - mint például a réz(II), a króm(III), (IV), (V), (VI), a vanádium(V) szintén adják a Haber-Weiss-reakciót [29].

A Ca másodlagos hírvivőként szerepet játszik a jelátviteli út múködésében, többek között a PLC, a PIP 2 , az $\mathrm{IP}_{3}$, a DAG, a PKC, a RAS/RAF/MAPK/ERK jelkaszkádban vesz részt (4. ábra). $\mathrm{A} \mathrm{NiSO}_{4}$ aktiválhatja a p38MAPK-t és az extracelluláris szignál szabályozta kinázt (ERK), amely képes a TNF $\alpha$-t felszabadítani [30].

A cink is másodlagos hírvivő a sejtben. Aktiválódása extracelluláris stressz, transzporterek, Zip7, ZnT hatására következik be, ami Ca-beáramlást és ERKl/2-aktivációt okoz. A sejtben megnó a Zn-szint, ami az endoplazmatikus reticulumból felszabaduló Zn-ből származik (5. ábra). A Zn-szint ezen átmeneti növekedését Znhullámnak nevezzük, amely transzkripciófüggetlen folyamat [31]. A sejtben lévő szabad cinkion legnagyobb forrása azonban a metallotionein $(\mathrm{MT})$, mivel a $\mathrm{Zn}^{2+}$ gyorsan képes felszabadulni a citoszolba a MT-ből nitrozilezéssel vagy tiol oxidációjával (6. ábra) [32]. Ezt a MT-oxidációt ultraibolya besugárzás, oxidatív stressz is

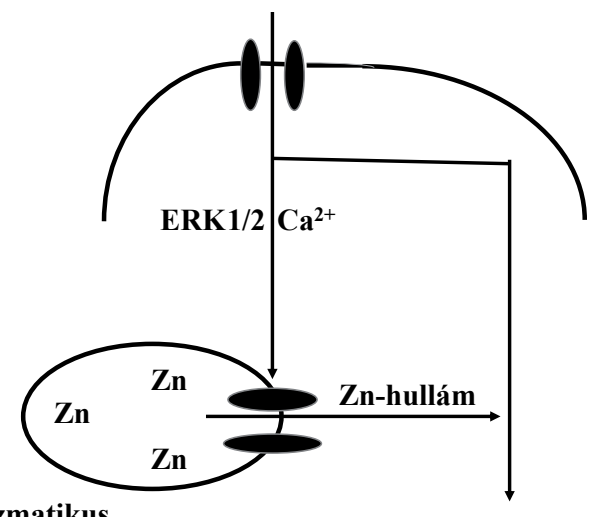

Endoplazmatikus reticulum

Gyulladásos citokinek

5. ábra $\quad$ Extracelluláris Zn felszabadulása $\mathrm{Ca}^{2+-}$ és ERKl/2 szignál aktiválásán át Fukada et al. (2011) alapján [33]

ERKl $/ 2$ = extracelluláris szignál szabályozta kináz-1/2 


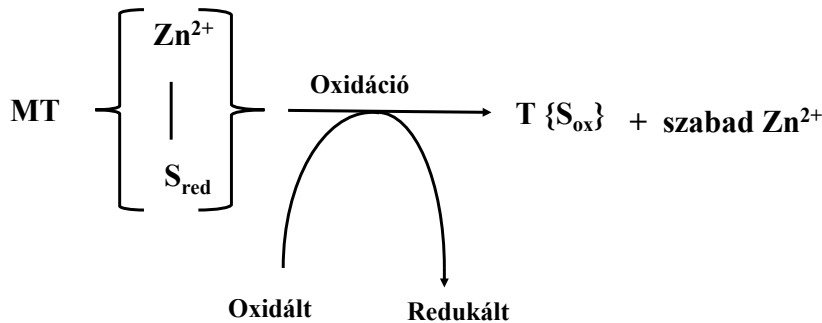

6. ábra $\mid$ Zn-felszabadulás metallotioneinből a tionein tiolcsoportjának oxidációjával, Maret (2000) alapján [32]

$\mathrm{MT}$ = metallotionein; $\mathrm{ROS}=$ reaktívoxigén-fajták; $\mathrm{T}$ = tionein

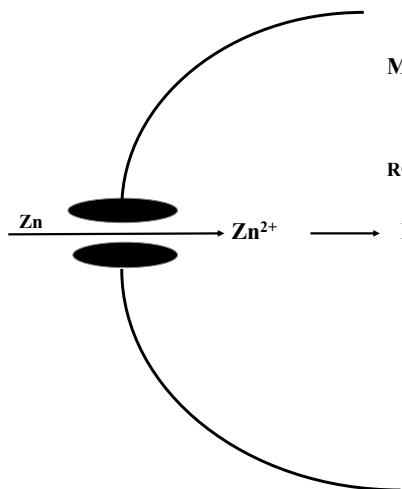

$\overbrace{\mathrm{ST}}^{\mathrm{S}}+\mathrm{Zn}^{2+}$

7. ábra

Nitrozilált metallotionein képződése Cousins et al. (2006) szerint [4]

iNOS = indukálható nitrogén-oxid-szintáz; MT = metallotionein; ROS = reaktívoxigén-fajták generálhatja, és gyors, tranziens emelkedést okoz a szabadcink-szintben [32]. A $\mathrm{Zn}^{2+}$ MT-ból való felszabadulásával a MTFl is aktiválódik, amely indukálja az iNOS-t, és emeli a NO-szintet, ami a MT tionitrozálódását okozza (7. ábra). A MT ilyen típusú oxidációja irreverzibilis és proinflammatoricus citokinek termelődésével jár, mint az IL1 $\beta$, IL6, ezenkívül befolyásolja a Zn-beáramlást, a STAT-közvetített jelátviteli útvonalat, valamint szabályozza a Zipl4-et és a Zip6-ot [5].

$\mathrm{Az}$ intracelluláris $\mathrm{Zn}$ felszabadulása révén aktiválódik néhány ioncsatorna (például a nagy vezetőképességü Caaktivált $\mathrm{K}^{+}$-csatorna, az ATP-aktivált $\mathrm{K}^{+}$-csatorna és a tranziens receptorpotenciál ankirin), ami a nitrozatív stressz elleni legfontosabb lépés. Az intracelluláris $\mathrm{Zn}^{2+}$ felszabadulás az előbb említett módon emeli a NO-szintet, a $\mathrm{Zn}^{2+}$ kötődése a $\mathrm{K}^{+}$-csatorna His365-höz azonban aktiválja a csatornát, és egyben csökkenti az intracelluláris Zn koncentrációját. A Zn hatást gyakorol még számos jelátviteli molekulára, mint például a PKC-ra, a Ca/ kalmodulinfüggő proteinkináz-II-re, az ERKl/2-re, a cAMP-függő proteinkinázra, a proteintirozin-foszfatázra, a kaszpáz-3-ra [33].

Hízósejtben az extracelluláris stimulus (például hisztamin, antigén) az FceRl-receptoron és a ZnT5-transzporteren keresztül citokintermelést okozhat (8. ábra). Ennek a folyamatnak még több része nem tisztázott, az azonban ismert, hogy a PKC cinkkötő motívumokkal rendelkezik, és ez kulcsfontosságú része a folyamatnak [34].

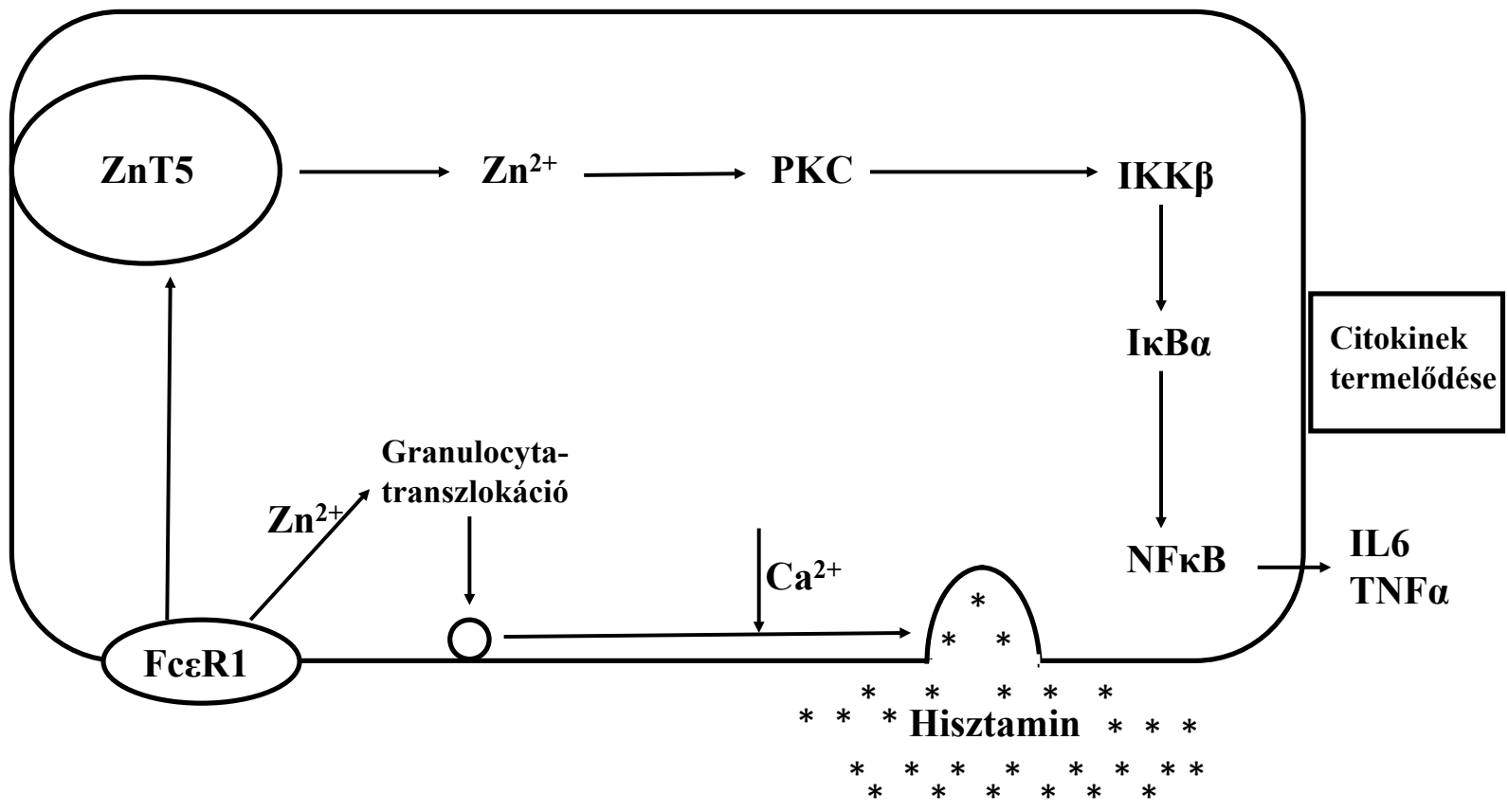

8. ábra $\quad$ Extracellulárisan indukált citokintermelés Fukada et al. (2011) alapján [33]

$\mathrm{F} c \varepsilon \mathrm{Rl}=$ immunglobulin-epszilon-receptor; $\mathrm{I} \kappa \mathrm{B} \alpha=\mathrm{a} \mathrm{NF}_{\kappa} \mathrm{B}$ gátlását szabályozó protein; $\mathrm{IKK} \beta=\mathrm{NF} \kappa \mathrm{B}$-inhibitor; IL6 = interleukin-6; NFkB = nukleárisfaktor-kappa- $\mathrm{B} ; \mathrm{PKC}=$ proteinkináz $\mathrm{C} ; \mathrm{TNF} \alpha=$ tumornekrózisfaktor-alfa $\mathrm{ZnT}=$ cinktranszporter 


\section{Szív- és érrendszeri, valamint anyagcsere-betegségek}

A vas számos szervben képes felhalmozódni, mint például a májban, a szívben, a hasnyálmirigyben. A felhalmozódott vas néhány év után kezd tüneteket (fáradtság, gyengeség) okozni, majd ez után alakulhatnak ki súlyos patológiás állapotok, mint a cirrhosis, májtumor, szívbetegség, neurodegeneratív betegségek vagy arthritis. A vastúlterhelés egyik tipikus következménye a nem genetikus eredetú haemochromatosis vagy az atherosclerosis is. A legtöbbször a belsőleges forrásból (transzferrin, ferritin, erythrocyta) felszabaduló vas, Fenton-reakción keresztül, szabad gyököket és oxidatív stresszt generálva oxidálja az LDL-t, mely kiindulási folyamat a kulcsa az atherosclerosis kialakulásának és számos következményes betegségnek [35].

A metabolikus szindróma, mely több betegséget foglal magában - mint az obesitas, az inzulinrezisztencia, a magas vérnyomás és a megemelkedett trigliceridszint -, öszszefüggést mutat a diabetes és a szívbetegségek kialakulásának kockázatával. A vastúlterhelés a 2-es típusú diabetes kockázatát is növeli, hat az inzulin kiválasztására és az apoptózis aktiválására is a hasnyálmirigy $\beta$-sejtjeiben. A májban a megemelkedett vasszint inzulinrezisztenciát válthat ki, a máj glükóztermelése károsodik. Az izom- és zsírsejtek, valamint a májsejtek glükózfelvétele is csökken, a májnak egyre több inzulinra van szüksége ahhoz, hogy a glükóz sejtbe jusson, ez azonban csak egy bizonyos szintig fokozható, ezért a máj glükóztermelése megnő [36]. Diabeteses betegekben emelkedett a Cu- és ceruloplazminszint, ami összefüggést mutat a szövődményként jelentkező magas vérnyomással és retinopathiával. A diabetesre jellemző még a nagyobb glikált fehérjék szintje is. E fehérjéknek nagy affinitásuk van az átmeneti fémionok megkötéséhez, azonban a kötött fémek, így a réz is megtartja ROS-generáló képességét, ami hozzájárul a diabeteses oxidatív stresszhez [37].

A megemelkedett réz- és ceruloplazminszint olyan gyulladásos megbetegedésre is jellemző, mint az arthritis, ahol a réz kapcsolódása biztosítja a szabad átmeneti fémion lekötését, megakadályozva ROS termelődését [38].

A réztranszportért felelős $A T P 7 B$-gén mutációja következtében kialakuló Wilson-kórban a betegség tünetei közé tartozik a réz akkumulálódása a májban, az agyban és más szervekben is, ami által réz katalizálta oxidatív stressz következik be [39].

\section{Neurológiai betegségek}

Egyes redoxaktív fémek homeosztázisának megváltozása olyan neurológiai betegségek kialakulásában is szerepet játszik, mint például az Alzheimer (AK)- vagy a Parkinson (PK)-kór.

AK esetében megnövekszik az oxidált DNS szintje, a MDA-szint, csökken az energiametabolizmus, gátolt a citokróm c-oxidáz szintézise, és számos lipidperoxidációra utaló marker jelenléte mutatható ki. A fóleg amiloid- $\beta$ peptid $(A \beta)$ alkotta amiloidplakk egy része kapcsolódik az idegsejtek membránfehérjéihez, melyek egy része Gproteinhez kötött. Ennek hatására Ca-ionok áramlanak be a sejtbe, és aktiválják a proteinkinázokat (például Cdk5, GSK3 $\beta$ ), és nagy mennyiségű szabad gyök képződik [40]. Az A $\beta$ által kiváltott szabadgyök-képződésben redoxaktív fémek is szerepet játszanak, mint a vas vagy a réz. Az A $\beta$ N-terminálisának hisztidin- (Hisl3, Hisl4, His6) és tirozin- (Tyr10) részeivel a szabad réz nagy affinitású komplexet képez, melyben a $\mathrm{Cu}(\mathrm{II})$-t a C-terminális metionin (Met35) redukálja $\mathrm{Cu}(\mathrm{I})$-gyé, miközben $\operatorname{Met}(35) S^{+}$szulfidgyök képződik. Ez a szulfidgyök képes reagálni a szuperoxidgyökkel metionin-szulfoxidot képezve, amit kimutattak AK-ban szenvedő betegekben. Az említett mechanizmuson felül az A $\beta$ peptid képes $\mathrm{Zn}$ ionokat is megkötni és ezáltal amiloidplakkokat generálni. Megemlítendő, hogy csak a Zn-kel képes a peptid plakk-képzésre, mert ebben az esetben konformációváltozás is történik. A folyamat a megváltozott cinkhomeosztázissal kapcsolható össze, és maga után vonja a metallotionein és a cinkfüggő metalloproteinek expreszsziójának megváltozását, köztük például a kétértékú fémtranszporter-1-ét (DMTl) is [41].

A Creutzfeldt-Jakob-betegségben egy fertőző amiloid, a prionfehérje $\left(\mathrm{PrP}^{\mathrm{CS}}\right)$ a szervezetbe bejutva vagy ott kialakulva, a környezetében lévő hasonló térszerkezetû́ fehérjét $\left(\operatorname{PrP}^{\mathrm{C}}\right)$ endocytosissal átalakítja. A molekuláris mechanizmus a mai napig nem tisztázott, azonban számos részletet ismerünk, amelyben a réznek is fontos szerepe van. A prion egy rézkötő fehérje, és rézfüggő SODaktivitással rendelkezik; az N-terminálison kötött rézionok biztosítják a szerkezeti stabilitását. A fehérje nagyobb mértékú expressziója esetén a réz felvételével növeli a sejt stabilitását, ami növeli az réztoxicitás és az oxidatív stressz elleni rezisztenciát. Nagy mennyiségú szabad $\mathrm{Cu}(\mathrm{II})$-ion azonban indukálhatja az endocytosist, megváltoztathatja a $\operatorname{PrP}^{\mathrm{C}}$ szerkezetét, átalakulási képességét, ugyanakkor oxidatív stresszt generálhat, ami növeli a $\operatorname{PrP}^{\mathrm{C}}$-szintet [42].

Parkinson-kórban számos folyamat utal nagymértékü oxidatív stresszre. A substantia nigra sejtjeiból a glutation gyors kiürülése történik, ami hatással van a mitokondriális energiatermelésre. PK-s betegek agyában nagyobb vasszintet detektáltak, ami szintén az oxidatív stresszet növeli, és hozzájárul a neurodegenerációhoz [43].

A Huntington-kór is tipikusan oxidatív stressz okozta idegrendszeri megbetegedés, melyben nagy mennyiségú oxidált fehérjék keletkeznek, bár a pontos hatásmechanizmusról, annak részleteiről nem sok információ van. Öröklődő, génmutációval járó, a vasanyagcserét befolyásoló betegség a Friedreich-ataxia. Az FXN-gén mutációja a mitokondriális frataxin koncentrációját csökkenti, amely egy vas-chaperonfehérje, és a mitokondriális légzési láncban kulcsfontosságú szerepet játszik a vasnak a 
vas-kén klaszterbe történő beépülését segítve. E folyamat károsodásával vasfelszabadulás következik be, ami hidroxilgyököket generál az ismert Fenton-reakción keresztül [44].

Számos egyéb kórkép van, melynek során vasfelhalmozódás történik elsősorban az agyban, de más szerveket is érinthet, így a májat, a retinát, a hasnyálmirigyet, mint például az aceruloplasminaemiában, a pantotenát-kinázzal összefüggő neurodegenerációban.

Arzén okozta neurológiai rendellenesség lehet a memóriazavar, a kognitív károsodás, az encephalopathia, valamint a neuropathia, a legkülönfélébb tünetekkel, mint például a túlzott vagy gyengült érzékenység, hányinger, hányás. Az arzén képes a szignál jelátviteli utat befolyásolni, hatással van a mitogénaktivált proteinkinázokra (MAPKs), transzkripciós faktorokra (NFkB, APl), a tirozin foszforilálására a tirozin-kinázokon (például RTKs) és a növekedési faktorokon (EGFR, VEGF) keresztül. A metilációs utakat is károsítja, ezáltal például a mielin bázikus fehérje argininrészeinek metilezettsége csökken. Az As okozta oxidatív stressz következménye az idegsejt DNS-károsodása és apoptózisa. Nő a sejten belüli Ca-koncentráció és a szabadgyök-képződés. Az arzén rövid idejü hatására az antioxidáns enzimek (SOD, kataláz, GPx) aktivitása növekszik, míg hosszabb távú expozíció esetén az enzimaktivitások csökkennek.

\section{Tumoros megbetegedések}

Bizonyított, hogy nagy mennyiségű esszenciális és/vagy nem esszenciális fém bevitele az emberi szervezetbe a tumor kockázatát növeli, a tumoros folyamatok megnövekedését okozza [8, 45]. Bizonyos elemek, például a toxikus $\mathrm{Pb}, \mathrm{Cd}, \mathrm{Hg}$ és Pt hatására nagymértékú akkumuláció következik be a vesében, és a multidrogrezisztencia-Pglikoprotein Mdrl up-regulációja figyelhető meg [27]. Az arzén elsősorban a szulfhidrilcsoportokhoz kötődik, és elfoglalja a $\mathrm{Zn}$ helyeit, aminek hatására gátolja a $\mathrm{Zn}$ (II)-ujj-motívumokkal rendelkező enzimek múködését.

A mutagenezis, a karcinogenezis és az öregedés folyamatának fontos lépése a biomolekulák módosulása. A szabad gyökök mellett a vas és egyéb átmeneti fémek által katalizált folyamatokban képződő szabad gyökök is módosíthatják az olyan biomolekulákat, mint a DNS. A nem vegyértékváltó fémek esetében, mint például a Cd, szintén oxidatív stressz történik, azonban más mechanizmussal. Részben a glutation kiürítésével hat, részben a redoxaktív fémek kicserélésével gátolja az olyan antioxidáns enzimek múködését, mint például a SOD és a kataláz. A tumorszövetekben jellemző a DNS károsodása, sokféle oxidált DNS-molekula képződik. A DNS guaninegységének 8-hidroxi-guaninra történő oxidációja jellemző a DNS oxidatív károsodására, azonban az adenin-, timin-, uracil- és citozinbázisok is képesek a Fenton-reakcióban képződő hidroxilgyökökkel adduktot képezni. Epidemiológiai és modellvizsgálatok bizo- nyítják, hogy a nagy vastartalmú sok vörös hús fogyasztása, valamint az alacsony rosttartalmú étkezés a Fenton-reakció által és a hidroxilgyök-képződéssel növeli a vastag- és végbéltumor előfordulását [46].

$\mathrm{Az}$ is ismert, hogy a szérumrézszint magasabb a tumoros betegekben (például Hodgkin-kór, leukaemia, sarcoma, tüdő-, emlő-, méhnyak-, májtumor), mint az egészséges emberekben, és a daganatos szövet nagyobb mértékben halmozza a rezet, mint más, egészséges szövetek. A legtöbb tumortípus esetében alacsonyabb a SOD és a kataláz szintje, valamint a GSH/GSSG aránya. Ugyanakkor megállapítást nyert, hogy a cink-, vas- és szelénhiány a tumoros folyamatok emelkedését vonja maga után [47].

Nagy mennyiségü kalcium bevitelének hatása a tumor kockázatára és a biológiai folyamatokra az irodalom szerint ellentmondásos. Az élő rendszerekben a kalciumion különös szerepet játszik mint elsődleges és másodlagos hírvivő. Bebizonyosodott, hogy a magas kalciumbevitel az elsődleges hírvivő szignál aktiválódását okozhatja, és ezáltal nagyobb kalciumbeáramlást biztosít a sejtbe. A sejt magasabb Ca-szintje másodlagos hírvivóként aktiválja a sejt molekuláris folyamatait, amelyek apoptózishoz, nekrózishoz vagy proliferációhoz vezetnek. Ennek ellenére mégsem találtak szoros és közvetlen összefüggést a Ca-bevitel és a tumoros folyamatok között, így például a prosztatatumorra vonatkozó eredmények a mai napig nem egyértelmúek. Noha egyes tanulmányok a prosztatatumor magas kockázatát bizonyították az étkezési kalcium nagyobb mennyiségü bevitele esetében, más szerzők nem találtak semmiféle összefüggést, vagy negatív kapcsolatot tapasztaltak közöttük. Hasonló eredményeket kaptak colorectalis tumorban. Nőknél és dohányzók esetében különösen a magasabb Ca-bevitel csökkentette az emlőtumor kockázatát [48]. Ezek az eredmények azonban még nem adnak elegendő bizonyítékot a nagy Ca-bevitel és a tumorkockázat kapcsolatának megerősítésére.

A cinkhiány befolyásolja a $\mathrm{NF}_{\kappa} \mathrm{B}$, az APl és az antionkogének, például a p53 (tumor suppressor protein) müködését, gátolja a p53 DNS-kötő képességét. Így közvetetten bár, de a cinkhiány DNS-károsodást okoz, és károsodik a DNS-javító mechanizmus is. Számos tumortípusnál, így például az emlő-, epehólyag-, fej-, nyaktumornál csökkent szérumcinkszintet detektáltak, ugyanakkor maga a tumorszövet akkumulálja a cinket, a bőr- és prosztatatumort kivéve [49].

\section{Következtetések}

Az oxidatív stressz és a fémion-homeosztázis között öszszefüggés van, ami a patológiás folyamatokban is nyomon követhető. Az oxidatív stressz fémelemhiányt vált ki a sejtekben és a szövetekben, és ez a fémfüggő antioxidáns védelmi rendszer (SOD, kataláz, GPx) alulmúködését okozza. Ugyanakkor a fémelem-homeosztázis megváltozása valamely elem hiányához vagy akkumuláci- 
ójához vezethet, ami szintén oxidatív stresszt vált ki. Elsősorban az átmeneti fémionoknak van fontos szerepük, azonban a nem változó vegyértékü fémionok is részt vesznek e folyamatokban, bár más módon és mechanizmussal hatnak. Az oxidatív stressz és a fémion-metabolizmus megváltozása következtében számos megbetegedés alakulhat ki vagy érintett, mint például cirrhosis, szívbetegség, neurodegeneratív betegségek, diabetes, arthritis, Wilson-kór, Alzheimer-kór, Parkinson-kór, Hodgkin-kór, leukaemia, sarcoma, tüdő-, emlő-, méhnyak-, májtumor.

Anyagi támogatás: A szerző anyagi támogatásban nem részesült.

A szerző a cikk végleges változatát elolvasta és jóváhagyta.

Érdekeltségek: A szerzőnek a dolgozatban foglaltakkal kapcsolatban nincsenek érdekeltségei.

\section{Irodalom}

[1] Kong AN, Yu R, Chen C, et al. Signal transduction events elicited by natural products: role of MAPK and caspase pathways in homeostatic response and induction of apoptosis. Arch Pharm Res. 2000; 23: 1-16.

[2] Ushio-Fukai M, Alexander RW. Reactive oxygen species as mediators of angiogenesis signaling: role of $\mathrm{NAD}(\mathrm{P}) \mathrm{H}$ oxidase. Mol Cell Biochem. 2004; 264: 85-97.

[3] Blázovics A. Small molecules in cancer therapy: cytotoxics and molecularly targeted agents. Curr Sign Trans Ther. 2011; 6: 2-19.

[4] Cousins RJ, Liuzzi JP, Lichten LA. Mammalian zinc transport, trafficking, and signals. J Biol Chem 2006; 281: 24085-24089.

[5] McLaren SH, Gao D, Chen L, et al. Oxidative stress and DNA damage - DNA repair system in vascular smooth muscle cells in artery and vein grafts. J Cardiothorac Renal Res. 2006; 1: 5972 .

[6] Agarwal A, Gupta S, Sharma RK. Role of oxidative stress in female reproduction. Reprod Biol Endocrinol. 2005; 3: 28.

[7] Szentmihályi K. Metal element homeostasis and free radicals. In: Blázovics A, Mézes M, Rőth E. (eds.) Oxidative stress and diseases. [Fémelemhomeosztázis és szabad gyökök. In: Blázovics A, Mézes M, Rőth E. (szerk.) Oxidativ stressz és betegségek.] Szent István Egyetemi Kiadó Nonprofit Kft. Nyomda, Gödöllő, 2015 pp. 66-71. [Hungarian]

[8] Chen F, Ding M, Castranova V, et al. Carcinogenic metals and NF- $\kappa$ B activation. Mol Cell Biochem. 2001; 222: 159-171.

[9] Drevs J, Medinger M, Schmidt-Gersbach C, et al. Receptor tyrosine kinases: the main targets for new anticancer therapy. Curr Drug Targets 2003; 4: 113-121.

[10] George D. Platelet-derived growth factor receptors: a therapeutic target in solid tumors. Semin Oncol. 2001; 28(5 Suppl 17): $27-33$.

[11] Wu W, Graves LM, Jaspers I, et al. Activation of the EGF receptor signaling pathway in human airway epithelial cells exposed to metals. Am J Physiol. 1999; 277: L924-L931.

[12] Posey T, Weng T, Chen Z, et al. Arsenic-induced changes in the gene expression of lung epithelial L2 cells: implications in carcinogenesis. BMC Genomics 2008; 9: 115 .
[13] Kurasaki M, Okabe M, Saito S, et al. Histochemical characteriza tion of silver-induced metallothionein in rat kidney. J Inorg Biochem. 2000; 78: 275-281.

[14] Saito S, Okabe M, Kurasaki M, et al. Role of rat metallothionein on zinc, cadmium and copper accumulation in hepatic and renal cytosol after heavy metal injection. Biomed Res Trace Elem. 1998; 9: 129-130.

[15] Szentmihályi K, Fehér E, Vinkler P, et al. Metabolic alterations of toxic and nonessential elements by the treatment of Sempervivum tectorum extract in a hyperlipidemic rat model. Toxicol Pathol. 2004; 32: 50-57.

[16] Rayssiguier Y, Libako P, Nowacki W, et al. Magnesium deficiency and metabolic syndrome: stress and inflammation may reflect calcium activation. Magnes Res. 2010; 23: 73-80.

[17] Lakatos B, Szentmihályi K, Vinkler P, et al. The role of essential metal ions in the human organism and their oral supplementation to the human body in deficiency states. [Az esszenciális fémionok szerepe az emberi szervezet múködésében, hiányuk pótlása orális úton.] Orv Hetil. 2004; 145: 1315-1319. [Hungarian]

[18] Forthergill KE, Ensminger ME. Childhood and adolescent antecedents of drug and alcohol problems: a longitudinal study. Drug Alcohol Depend. 2006; 82: 61-76.

[19] Bekő G, Hagymási K, Szentmihályi K, et al. Sex-dependent alterations in erythrocyte trace element levels and antioxidant status after a month of moderate daily red wine consumption. Eur J Gastroenterol Hepatol. 2010; 22: 185-191.

[20] Walter RM Jr, Uriu-Hare JY, Olin KL, et al. Copper, zinc, manganese, and magnesium status and complications of diabetes mellitus. Diabetes Care 1991; 14: 1050-1056.

[21] Leonard S, Gannett PM, Rojanasakul Y, et al. Cobalt-mediated generation of reactive oxygen species and its possible mechanism. J Inorg Biochem. 1998; 70: 239-244.

[22] Salnikow K, Zhitkovich A. Genetic and epigenetic mechanisms in metal carcinogenesis and cocarcinogenesis: nickel, arsenic, and chromium. Chem Res Toxicol. 2008; 21: 28-44.

[23] Shi XL, Dalal NS. Flavoenzymes reduce vanadium(V) and molecular oxygen and generate hydroxyl radical. Arch Biochem Biophys. 1991; 289: 355-361.

[24] Mishra D, Flora SJ. Differential oxidative stress and DNA damage in rat brain regions and blood following chronic arsenic exposure. Toxicol Ind Health 2008; 24: 247-256.

[25] Wätjen W, Beyersmann D. Cadmium-induced apoptosis in C6 glioma cells: influence of oxidative stress. Biometals 2004; 17: 65-78.

[26] Ognjanović BI, Pavlović SZ, Maletić SD, et al. Protective influence of vitamin $\mathrm{E}$ on antioxidant defense system in the blood of rats treated with cadmium. Physiol Res. 2003; 52: 563-570.

[27] Sabolić I, Breljak D, Herak-Kramberger CM, et al. Expression of multidrug resistance $\mathrm{P}$-glycoprotein $\mathrm{Mdrl}(\mathrm{Abcbl})$ in rat kidney proximal tubules is up-regulated by nephrotoxic metals. Metal Ions Biol Med. 2008; 10: 315-321.

[28] Henle ES, Linn S. Formation, prevention, and repair of DNA damage by iron hydrogen peroxide. J Biol Chem. 1997; 272: 19095-19098.

[29] Stephen RL, Gustafsson MC, Jarvis M, et al. Activation of peroxisome proliferator-activated receptor delta stimulates the proliferation of human breast and prostate cancer cell lines. Cancer Res. 2004; 64: 3162-3170.

[30] Miyazawa M, Ito Y, Kosaka N, et al. Role of MAPK signaling pathway in the activation of dendritic type cell line, THP-1, induced by DNCB and $\mathrm{NiSO}_{4}$. J Toxicol Sci. 2008; 33: 51-59.

[31] Yamasaki S, Sakata-Sogawa K, Hasegawa A, et al. Zinc is a novel intracellular second messenger. J Cell Biol. 2007; 177: 637-645.

[32] Maret W. The function of zinc metallothionein: a link between cellular zinc and redox state. J Nutr. 2000; 130(Suppl): 1455S1458 S 
[33] Fukada T, Yamasaki S, Nishida K, et al. Zn-homeostasis and signaling in health and diseases. Zinc signaling. J Biol Inorg Chem. 2011; 16: 1123-1134.

[34] Bernal PJ, Bauer EM, Cao R, et al. A role for zinc in regulating hypoxia-induced contractile events in pulmonary endothelium. Am J Physiol Lung Cell Mol Physiol. 2011; 300: L874-L886.

[35] Valko M, Jomova K, Rhodes CJ, et al. Redox- and non-redoxmetal-induced formation of free radicals and their role in human diseases. Arch Toxicol. 2016; 90: 1-37.

[36] Leiva E, Mujica V, Sepúlveda P, et al. High levels of iron status and oxidative stress in patients with metabolic syndrome. Biol Trace Elem Res. 2013; 151: 1-8.

[37] Uriu-Adams JY, Keen CL. Copper, oxidative stress, and human health. Mol Aspects Med. 2005; 26: 268-298.

[38] Sokolov AV, Acquasaliente L, Kostevich VA, et al. Thrombin in hibits the anti-myeloperoxidase and ferroxidase functions of ceruloplasmin: relevance in rheumatoid arthritis. Free Radic Biol Med. 2015; 86: 279-294.

[39] Huster D. Wilson disease. Best Pract Res Clin Gastroenterol. 2010; 24: 531-539.

[40] Hardy JA, Higgins GA. Alzheimer's disease: the amyloid cascade hypothesis. Science 1992; 256: 184-185.

[41] Jomova K, Baros S, Valko M. Redox active metal-induced oxidative stress in biological systems. Transition Met Chem. 2012; 37: $127-134$.

[42] Hordyjewska A, Popiołek $€$, Kocot J. The many "faces" of copper in medicine and treatment. Biometals 2014; 27: 611-621.
[43] Jomova K, Vondrakova D, Lawson M, et al. Metals, oxidative stress and neurodegenerative disorders. Mol Cell Biochem. 2010; 345: 91-104.

[44] Huang ML, Becker EM, Whitnall M, et al. Elucidation of the mechanism of mithochondrial iron loading in Friedreich's ataxia by analysis of a mouse mutant. Proc Natl Acad Sci USA 2009; 106: 16381-16386.

[45] Snow ET. Metal carcinogenesis: mechanistic implications. Pharmacol Ther. 1992; 53: 31-65.

[46] Halliwell B, Zhao K, Whiteman M. The gastrointestinal tract: a major site of antioxidant action? Free Radic Res. 2000; 33: 819830.

[47] Ames BN. DNA damage from micronutrient deficiencies is likely to be a major cause of cancer. Mutation Res. 2001; 475: 7-20.

[48] Hjartåker A, Thoresen M, Engeset D, et al. Dairy consumption and calcium intake and risk of breast cancer in a prospective cohort: the Norwegian Women and Cancer study. Cancer Causes Control 2010; 21: 1875-1885.

[49] Costello LC, Franklin RB. The clinical relevance of the metabolism of prostate cancer, zinc and tumor suppression: connecting to dots. Mol Cancer 2006; 5: 17.

(Szentmihályi Klára dr., Budapest, Magyar tudósok körútja 2., 1117 e-mail: szentmihalyi.klara@ttk.mta.hu)

\section{„Repetitio est mater studiorum." (Ismétlés a tudás anyja.)}

A cikk a Creative Commons Attribution 4.0 International License (https://creativecommons.org/licenses/by/4.0/) feltételei szerint publikált Open Access közlemény, melynek szellemében a cikk bármilyen médiumban szabadon felhasználható, megosztható és újraközölhetö, feltéve, hogy az eredeti szerző és a közlés helye, illetve a CC License linkje és az esetlegesen végrehajtott módosítások feltüntetésre kerülnek. (SID_1) 